\title{
Effects of partial replacement of barley with rapeseed oil or birch wood in comparison to barley and oats on the performance and blood metabolites of lactating cows
}

\author{
Alem Tsehai Tesfa, Mikko Tuori, LiISA Syrjälä-Qvist and Kaisa Kaustell
}

Tesfa, A. T., TUORI, M., SYrJÄLÄ-Qvist, L. \& KAUSTEll, K. 1992. Effects of partial replacement of barley with rapeseed oil or birch wood in comparison to barley and oats on the performance and blood metabolites of lactating cows. Agric. Sci. Finl. 1: 255-265. (Univ. Helsinki, Dept. Anim. Sci. SF-00710 Helsinki, Finland.)

\begin{abstract}
Barley was partially replaced with either rapeseed oil (RSO), unextracted steamexploded birch wood (W1) or extracted steam-exploded birch wood (W2), and fed to 10 lactating cows ( 5 multiparous and 5 primiparous cows) in comparison to rolled barley and oats. The experiment was designed in two balanced 5 x 5 Latin squares. The experimental periods lasted for 4 weeks and the cows were fed with a fixed amount of $8 \mathrm{~kg}$ (air dry basis) concentrate in two equal portions. Timothy dominant unwilted grass silage was provided ad libitum. The nutrient digestibility, blood metabolites, milk yield and composition were studied.

Grass silage intake decreased by replacing barley with RSO and increased with W1 and W2. Oat feeding also increased silage intake compared to barley feeding. Oat feeding decreased the digestibility of the organic matter (OM) compared to barley. No significant difference was observed between diets in plasma concentrations of insulin, free fatty acids, acetoacetate, B-hydroxybutyrate and glucose. Replacing part of the barley with RSO increased milk yield by $1.3 \mathrm{~kg}$ and $0.87 \mathrm{~kg}$ compared to oats and barley feeding, respectively. Replacement of barley by low energy birch wood decreased milk yield. Both RSO and oat feeding decreased milk protein content. Milk urea concentration was elevated by oats and depressed by RSO and birch wood. RSO and oat feeding decreased the short chain fatty acid content of milk, with a concomitant increase in stearic and oleic acids.
\end{abstract}

Key words: milk yield, fatty acids, insulin, glucose

\section{Introduction}

Grain has been partly replaced or supplemented by fats and oil for dairy cows with the aim of increasing the energy density of the diet. Recently, fats have been included in an attempt to alter the fatty acid composition of milk, thereby improving its nutritional and physical properties. Direct feeding of oil/fat to a cow on the farm creates day-to-day handling problems due to their organoleptic character which limits their acceptance. An alternative approach to dietary manipulation of the fatty acid composition of milk fat is to feed lactating dairy cows with oats (LAMPILA and HEIKKILÄ 1986; MARTIN and THOMAS 1988), because oats contain more lipid than barley or wheat, and its fatty acids are highly unsaturated (MORRISON 1977).

The digestibility of lignocellulosic materials like wood and wood products has been improved by chemical or steam treatments (TARKOW and FEIST 1969; BENDER et al. 1970; REDDY et al. 1972). Steam explosion is a method, where wood chips are 
steamed using saturated steam of over $200^{\circ} \mathrm{C}$ and a high speed discharge of steamed wood into the air, utilizing the concept of making popcorn. After the process, the hemicellulose of hardwood is hydrolysed into a low molecular substance and it becomes water soluble. Cellulose is easily decomposed by enzymes, lignin is degenerated, and part of it becomes soluble (TAKIGAWA 1987). A 49-60 \% digestibility has been obtained for steam-exploded aspen wood and white birch (TERADA et al. 1986, ref. TAKIGAWA 1987, TUORI 1990). Replacement of the dry matter of corn silage by $20 \%$ of steam-exploded aspen wood had no influence on milk yield or milk composition (FISHER 1980). In Japan, when steamed white birch comprised $15 \%$ of dairy cow ration, it had no influence on yield, but $30 \%$ of wood tended to decrease production (Мгуамото et al. 1986, ref TAKIGAWA 1987).

In Finland, birch wood is used as raw material by xylitol manufacturers. Using the steam explosion method for birch wood it would be possible to separate hydrolysed xylans for further processing. In this experiment, the effect of substituting barley with rapeseed oil or steam-exploded birch wood and water-extracted steam-exploded wood (xylans removed) on milk production was studied. The effect of oats and rapeseed oil feeding on the fatty acid composition of milk fat was compared to that of barley feeding.

\section{Material and methods}

\section{Experimental design and animals}

Five primiparous (PP) and five multiparous (MP) Ayrshire cows that had calved on average 46 days before the start of the experiment, were used in a two balanced $5 \times 5$ Latin square design (MP and PP cows in separate squares). Each experimental period lasted for four weeks. Data from weeks 3 and 4 were used for the statistical analysis. One cow ceased eating before the completion of the fifth period, and the data on the oat diet was calculated only on four observations.

\section{Feeds and feeding}

The concentrate feed was formulated as shown in Table 1. The first two grain feeds were rolled barley (barley) and rolled oats (oats). An equal amount (w/w) of rolled barley was replaced either by $0.4 \mathrm{~kg}$ rapeseed oil (RSO), $2 \mathrm{~kg}$ unextracted steam-exploded birch wood (W1), or $2 \mathrm{~kg}$ water-extracted steam-exploded birch wood (W2). W1 and W2 were lignocellulosic materials which were steamexploded (Stake-process) under a pressure of $14 \mathrm{~kg}$ per $\mathrm{cm}^{2}$ at $210^{\circ} \mathrm{C}$ for $5 \mathrm{~min}$ to break the cell wall material and to facilitate digestion (BENDER et al. 1970). Degraded xylans were removed from W2 by water extraction. Both $\mathrm{W} 1$ and $\mathrm{W} 2$ were in a form of finely ground wad and were easy to mix with barley. RSO was from a double zero (00) variety of Brasica campestris. All cows received $1.3 \mathrm{~kg}$ ( $16 \%$ of concentrate) soya bean meal as protein supplement. Each ingredient replacing rolled barley was mixed manually with the barley before each meal.

The cows were fed individually twice a day at $0600 \mathrm{~h}$ and $1400 \mathrm{~h}$. Concentrate was offered $8 \mathrm{~kg}$ (air dry) $\mathrm{d}^{-1}$ and first cut unwilted grass silage was given ad libitum throughout the trial. All diets were supplemented with a mineral mixture fed at a rate of $250 \mathrm{~g} \mathrm{~d}^{-1}$. The apparent digestibility of feeds was determined on five multiparous cows using chromium oxide $\left(\mathrm{Cr}_{2} \mathrm{O}_{3}\right)$ as an external marker. $\mathrm{Cr}_{2} \mathrm{O}_{3}$ impregnated paper $(20 \mathrm{~g} \mathrm{Cr}$ per day in two por-

Table 1. Feed ingredients, kg (air dry basis).

\begin{tabular}{|c|c|c|c|c|c|}
\hline \multirow[t]{2}{*}{ Ingredients } & \multicolumn{5}{|c|}{ Dietary groups } \\
\hline & Barley & Oats & RSO & W1 & W2 \\
\hline Rolled barley & 6.7 & - & 6.3 & 4.7 & 4.7 \\
\hline Rolled oats & - & 6.7 & - & - & \\
\hline Soya bean meal & 1.3 & 1.3 & 1.3 & 1.3 & 1.3 \\
\hline Rapeseed oil & - & - & 0.4 & - & \\
\hline $\begin{array}{l}\text { Unextracted steam- } \\
\text { exploded birch wo } \\
\text { Extracted steam- }\end{array}$ & ood & - & - & 2.0 & \\
\hline exploded birch wo & ood - & - & - & - & 2.0 \\
\hline Mineral Mix & 0.25 & 0.25 & 0.25 & 0.25 & 0.25 \\
\hline
\end{tabular}


tions) was introduced to the rumen using a stomach tube for eleven days on each period. The efficiency of utilization of metabolizable energy (ME) in milk production was calculated on the basis of digestible organic matter (5 MP cows).

\section{Recording and sampling}

The cows were weighed on two consecutive days at the beginning of the experiment, as well as in the middle and at the end of each period. The daily feed offered and refusals were recorded. The weekly feed samples were collected and pooled into one sample per diet per period. The $\mathrm{pH}$ and dry matter (DM) content were determined from the weekly sample of grass silage for quality control purposes. An extra weekly sample was frozen at $-18^{\circ} \mathrm{C}$ for the determination of fermentation characteristics.

The milk yield was recorded at each milking and sampled at four milkings during the two last weeks of each period for the determination of fat, protein, urea, lactose and fatty acids. Blood samples were collected from the jugular vein (Vena jugularis) into vacutainers on day 24 at $0,2,4$ and $6 \mathrm{~h}$ postmorning feeding. Plasma was separated by centrifuging at $2000 \mathrm{rpm}$ for $10 \mathrm{~min}$ and deep frozen at $-18^{\circ} \mathrm{C}$ until analysed for insulin and free fatty acids (FFA) concentration. Samples for B-hydroxybutyrate (BHBA) and acetoacetate (AA) analyses were immediately precipitated with $2 \mathrm{ml}$ of $0.6 \mathrm{M}$ perchloric acid to avoid loss of AA and kept at $-18^{\circ} \mathrm{C}$ (TYÖPPÖNEN and KAUPPINEN 1980). Faecal grab samples were collected rectally twice a day at 0800 and $1500 \mathrm{~h}$ for 6 days, starting on the 23 day, and stored at $-18^{\circ} \mathrm{C}$. At the end of the collection period, samples were thawed and pooled into one sample per treatment.

\section{Chemical analysis}

Feeds and milk samples were analyzed as described previously (TESFA et al. 1991). Faecal samples were analyzed for $\mathrm{DM}$ by drying at $105^{\circ} \mathrm{C}$ to constant weight, and for organic matter (OM) by ashing in a muffle furnace at $550^{\circ} \mathrm{C}$ for $24 \mathrm{~h}$. Fresh faecal and dried feed samples were determined for crude protein by the Kjeldahl method. Dried faecal and feed samples were used for the determination of neutral detergent fibre (NDF) and acid detergent fibre (ADF) (GOERING and VAN SOEST 1970). Chromium in faeces was determined by atomic absorption spectrophotometry (WILliams et al. 1962).

The blood glucose concentration was analyzed by the enzymatic glucoseoxidase and FFA by an enzymatic colorimetric method (Wako chemicals). Insulin was analyzed by radioimmunoassay using a double antibody solid phase technique (Phadeseph Insulin RIA). AA and BHBA were analyzed according to HANSEN and FREIER (1978) with a Gilford 3500 analyzer at a temperature of $37^{\circ} \mathrm{C}$ and a wavelength of $340 \mathrm{~nm}$. Milk urea was determined with an enzymatic colorimetric system according to RAJAMÄKI and RAURAMAA (1984).

\section{Statistical Analysis}

The data were analyzed by the least square analysis of variance using:

Model I. For apparent digestibility of nutrients: $\mathrm{Y}_{\mathrm{ijkl}}=\mu+\mathrm{C}_{\mathrm{i}}+\mathrm{D}_{\mathrm{j}}+\mathrm{P}_{\mathrm{k}}+\mathrm{e}_{\mathrm{ijk \textrm {k }}}$, where $\mu$ is the mean, and $\mathrm{C}, \mathrm{D}$, and $\mathrm{P}$ are cow, diet and period effects, resprctively, and $\mathrm{e}_{\mathrm{ijk \textrm {l }}}$ is the residual effect.

Model II. For production parameters:

$\mathrm{Y}_{\mathrm{ijklm}}=\mu+\mathrm{S}_{\mathrm{l}}+\mathrm{C}_{\mathrm{i}}\left(\mathrm{S}_{\mathrm{l}}\right)+\mathrm{P}_{\mathrm{k}}+\mathrm{D}_{\mathrm{j}}+(\mathrm{SP})_{\mathrm{lk}}+(\mathrm{SD})_{\mathrm{lj}}+$ $\mathrm{e}_{\mathrm{ijklm}}$,

where $\mathrm{C}, \mathrm{P}$, and $\mathrm{D}$ are as above. $\mathrm{S}$ is the square (parity) effect and SP is the square* period effect, $\mathrm{SD}$ is the square*diet effect and $\mathrm{e}_{\mathrm{ijk \textrm {km }}}$ is the error.

Model III.

Blood metabolites were analyzed using a split-plot analysis of variance using the following model: $\mathrm{Y}_{\mathrm{ijklm}}=\mu+\mathrm{S}_{1}+\mathrm{C}_{\mathrm{i}}\left(\mathrm{S}_{\mathrm{l}}\right)+\mathrm{P}_{\mathrm{k}}+\mathrm{D}_{\mathrm{j}}+\mathrm{e}_{\mathrm{ilkj}}+\mathrm{T}_{\mathrm{m}}+$ $\mathrm{T}_{\mathrm{m}}\left(\mathrm{C}_{\mathrm{i}}\left(\mathrm{S}_{\mathrm{l}}\right)\right)+(\mathrm{PT})_{\mathrm{km}}+(\mathrm{DT})_{\mathrm{jm}}+\mathrm{e}_{\mathrm{ikjlm}}$, where $\mathrm{T}_{\mathrm{m}}$ is the sampling time effect, $\mathrm{e}_{\mathrm{ikj}}$ is the main plot error, $T_{m}\left(C_{i}\left(S_{1}\right)\right)$ is the interaction between cow and sampling time; (PT)km, is the interaction between period and sampling time, (DT) $)_{\mathrm{jm}}$, is the interaction between diet and sampling time, and $\mathrm{e}_{\mathrm{ikjlm}}$ is the sub-plot error and $\mu$ is the constant. The differences 
between treatments were tested with Tukey's test (STEEle and Torrie 1960). Values given in Tables 3-8 are least square means of treatments.

\section{Results}

The mean chemical composition and feed values of feeds used are given in Table 2. As can be seen from Table 3, the total DM intake in barley and oat diets was equal. However, the cows fed with oats had more leftovers of concentrate. Silage intake decreased by $0.5 \mathrm{~kg}$ when RSO replaced part of the barley and increased by $0.6 \mathrm{~kg}$ with oat feeding.
The main difference in feed intake was the increased (1:1 kg DM) silage intake by cows fed on W2 increasing their total DM intake by $1 \mathrm{~kg}$ compared to barley or oats fed cows. Multiparous cows consumed $2.1 \mathrm{~kg}$ DM more than the PP cows.

\section{Feed apparent digestibility}

The digestion coefficients of dietary nutrients are given in Table 4. Oat feeding decreased $(\mathrm{P}<0.05)$ the digestibility of $\mathrm{OM}$ compared to barley. Crude protein $(\mathrm{CP})$ digestibility was higher $(\mathrm{P}<0.05)$ for the oat group than for the RSO group.

Table 2. Chemical composition of experimental feeds.

\begin{tabular}{|c|c|c|c|c|c|c|}
\hline & Silage & SBM & Barley & Oats & W1 & W2 \\
\hline $\mathrm{DM}, \mathrm{g} \mathrm{kg}^{-1}$ & 246 & 877 & 869 & 874 & 970 & 968 \\
\hline \multicolumn{7}{|l|}{ Compositions, $\mathrm{g} \mathrm{kg}^{-1} \mathrm{DM}$} \\
\hline Ash & 72 & 66 & 24 & 31 & 5 & 3 \\
\hline Crude protein & 162 & 486 & 139 & 157 & 7 & 8 \\
\hline Crude fat & 48 & 42 & 36 & 60 & 14 & 22 \\
\hline Crude fibre & 254 & 71 & 57 & 130 & 413 & 524 \\
\hline Nitrogen free extract & 461 & 335 & 744 & 622 & 561 & 444 \\
\hline Neutral detergent fibre & 490 & 123 & 211 & 330 & 583 & 728 \\
\hline Acid detergent fibre & 268 & 75 & 60 & 148 & 544 & 685 \\
\hline Acid detergent lignin & 20 & 3 & 10 & 27 & 71 & 86 \\
\hline \multicolumn{7}{|l|}{ Feed value } \\
\hline $\mathrm{ME}, \mathrm{MJ} \mathrm{kg}^{-1} \mathrm{DM}$ & 10.09 & 12.65 & 13.67 & 12.22 & 8.53 & 5.53 \\
\hline DCP, $\mathrm{g} \mathrm{kg}^{-1} \mathrm{DM}$ & 109 & 437 & 104 & 129 & - & - \\
\hline FFU, $\mathrm{kg}^{-1} \mathrm{DM}$ & 0.72 & 1.07 & 1.17 & 1.03 & 0.71 & 0.43 \\
\hline
\end{tabular}

SBM, soya bean meal; DCP, digestible crude protein; ME, Metabolizable energy (MAFF 1975); FFU, fattening feed units = $0.7 \mathrm{~kg}$ starch (SALo et al. 1982).

Table 3. Mean daily feed intake, $\mathrm{kg} \mathrm{DM} \mathrm{d}^{-1} \operatorname{cow}^{-1}$.

\begin{tabular}{|c|c|c|c|c|c|c|c|c|c|}
\hline & \multicolumn{6}{|c|}{ Dietary groups } & \multicolumn{3}{|c|}{ Cow parity } \\
\hline & Barley & Oats & RSO & W1 & W2 & SEM & MP & PP & SEM \\
\hline Total & 17.4 & 17.4 & 17.1 & 17.8 & 18.4 & 0.23 & 18.6 & 16.5 & 0.14 \\
\hline Silage & 10.6 & 11.2 & 10.1 & 10.8 & 11.7 & 0.25 & 11.7 & 10.0 & 0.16 \\
\hline Concentrate & 6.8 & 6.2 & 7.0 & 7.0 & 6.7 & 0.15 & 6.8 & 6.3 & 0.09 \\
\hline NDF & 6.6 & 7.4 & 6.3 & 7.5 & 8.0 & 0.11 & 7.6 & 6.6 & 0.06 \\
\hline Total fat & 0.75 & 0.88 & 1.12 & 0.72 & 0.77 & 0.13 & 0.89 & 0.78 & 0.01 \\
\hline $\mathrm{CP}$ & 2.99 & 3.05 & 2.90 & 2.81 & 2.92 & 0.04 & 3.10 & 2.76 & 0.03 \\
\hline ME MJ d ${ }^{-1}$ & 195 & 187 & 201 & 191 & 191 & 2.50 & 204 & 182 & 1.58 \\
\hline
\end{tabular}

See Table 2. for NDF and ME. CP, crude protein. 
Table 4. Digestibility coefficients of dietary nutrients.

\begin{tabular}{|c|c|c|c|c|c|c|}
\hline & \multicolumn{6}{|c|}{ Dietary groups } \\
\hline & Barley & Oats & RSO & W1 & W2 & SEM \\
\hline Dry matter & 0.737 & 0.697 & 0.710 & 0.705 & 0.685 & 0.0074 \\
\hline Organic matter & 0.752 & 0.709 & 0.725 & 0.717 & 0.696 & 0.0073 \\
\hline Crude protein & 0.718 & 0.737 & 0.700 & 0.699 & 0.710 & 0.0071 \\
\hline Ether extract & 0.575 & 0.633 & 0.610 & 0.544 & 0.560 & 0.0119 \\
\hline Neutral detergent fibre & 0.677 & 0.607 & 0.637 & 0.662 & 0.627 & 0.0127 \\
\hline Acid detergent fibre & 0.671 & 0.622 & 0.629 & 0.649 & 0.592 & 0.0131 \\
\hline
\end{tabular}

SEM, Standard error of mean.

Table 5. Effects of dietary treatment and cow status on blood acetoacetate (AA), B-hydroxybutyrate (BHBA), glucose and free fatty acids (FFA) $\left(\mathrm{mmol} \mathrm{l}^{-1}\right)$ and insulin $\left(\mathrm{mU} \mathrm{l}^{-1}\right)$.

\begin{tabular}{lrrrrrrrrr}
\hline & \multicolumn{3}{c}{ Dietary groups } & & & & & \multicolumn{2}{c}{ Cow parity } \\
& Barley & Oats & RSO & W1 & W2 & SEM & MP & PP & SEM \\
\hline AA & 0.142 & 0.143 & 0.154 & 0.161 & 0.144 & 0.016 & 0.154 & 0.144 & 0.010 \\
BHBA & 0.817 & 0.822 & 0.831 & 0.886 & 0.796 & 0.103 & 0.878 & 0.783 & 0.065 \\
FFA & 0.155 & 0.174 & 0.173 & 0.165 & 0.150 & 0.021 & 0.176 & 0.151 & 0.013 \\
Glucose & 2.58 & 2.52 & 2.57 & 2.46 & 2.57 & 0.102 & 2.52 & 2.56 & 0.064 \\
Insulin & 31.3 & 31.9 & 32.4 & 29.8 & 28.5 & 7.005 & 37.8 & 23.1 & 4.430 \\
\hline
\end{tabular}

MP, multiparous; PP, primiparous; SEM, standard error of mean.

\section{Blood metabolites}

Although there was some variation in blood metabolites between cows fed on the different diets, none of these differences were statistically significant, except for BHBA on W1 and W2 (Table 5). There was a slight increase in AA, FFA, BHBA and insulin concentration on RSO. Insulin concentrations slightly decreased on W1 and W2 diets. The blood metabolites of both multiparous and first lactation heifers were generally similar. However, blood insulin (23.1 vs 37.8$)$, blood FFA ( 0.151 vs $0.176)$ and BHBA $(0.786$ vs 0.878$)$ were lower for PP cows than for MP cows. No significant change in body weight $\left(0.22 \mathrm{vs} 0.10 \mathrm{~kg} \mathrm{~d}^{-1}\right)$ was observed between cow parity.

\section{Milk yield and composition}

The overall milk yield of cows fed with oats, W1 and W2 is lower as compared to barley fed cows. A more significant $(\mathrm{P}<0.01)$ difference was observed between cows fed on oats and RSO (Table 6). Slightly more milk fat was produced by animals fed on W1 as compared to those fed on W2. Replacement of barley with RSO decreased milk fat content and increased milk yield by $5.4 \%\left(0.87 \mathrm{~kg} \mathrm{~d}^{-1}\right)$ compared to barley, but this increment was not statistically significant (Table 6). A decrease $(\mathrm{P}<0.05)$ of milk protein content was observed in cows fed with oats and RSO compared to those fed with barley. The milk urea content of cows fed oats was increased $(\mathrm{P}<0.01)$; those fed with $\mathrm{W} 1$ and $\mathrm{W} 2$ showed a decrease $(\mathrm{P}<0.01)$ compared to those fed with barley. There was no significant difference between those fed with RSO and barley. Similar to their total feed intake, milk yield and FCM yield was significantly $(\mathrm{P}<0.001)$ higher for MP cows compared to PP.

The efficiency of utilization of ME in milk production is given in Table 7. There was no significant $(\mathrm{P}>0.10)$ difference in efficiency of utilization 
Table 6. Effects of diet and cow status on daily milk yield $(\mathrm{kg})$ milk composition $\left(\mathrm{g} \mathrm{kg}^{-1}\right)$, and live weight changes (LWC).

\begin{tabular}{|c|c|c|c|c|c|c|c|c|c|}
\hline & & & y grou & & & & & ow par & \\
\hline & Barley & Oats & RSO & W1 & W2 & SEM & MP & PP & SEM \\
\hline Yields, $\mathrm{kg} \mathrm{d}^{-1}$ & & & & & & & & & \\
\hline Milk & 24.6 & 24.2 & 25.5 & 23.3 & 22.9 & 0.30 & 26.6 & 21.4 & 0.19 \\
\hline FCM & 25.9 & 25.5 & 26.4 & 24.6 & 24.1 & 0.40 & 27.8 & 22.8 & 0.25 \\
\hline Fat & 1.07 & 1.05 & 1.08 & 1.02 & 0.99 & 0.016 & 1.14 & 0.94 & 0.010 \\
\hline Protein & 0.79 & 0.75 & 0.79 & 0.74 & 0.75 & 0.008 & 0.85 & 0.68 & 0.009 \\
\hline Lactose & 1.12 & 1.12 & 1.18 & 1.07 & 1.05 & 0.011 & 1.19 & 1.02 & 0.007 \\
\hline Compositions, $\mathrm{g} \mathrm{k}$ & & & & & & & & & \\
\hline Fat & 43.6 & 43.6 & 42.9 & 44.3 & 43.6 & 0.59 & 43.5 & 43.7 & 0.37 \\
\hline Protein & 32.4 & 31.1 & 31.4 & 32.2 & 32.7 & 0.58 & 32.3 & 32.1 & 0.36 \\
\hline Lactose & 45.6 & 46.2 & 46.5 & 45.9 & 46.0 & 0.26 & 45.0 & 47.1 & 0.16 \\
\hline Urea, $\mathrm{mg} 100^{-1} \mathrm{ml}$ & 31.6 & 37.6 & 30.8 & 27.6 & 29.5 & 0.75 & 30.1 & 32.6 & 0.47 \\
\hline LWC, $\mathrm{kg} \mathrm{d}^{-1}$ & -0.13 & 0.21 & 0.24 & 0.15 & 0.32 & 0.11 & 0.10 & 0.21 & 0.07 \\
\hline
\end{tabular}

$\mathrm{FCM}=0.4^{*}$ milk yield $+15^{*}$ fat yield; See Table 5 for MP, PP and SEM.

Table 7. Efficiency of utilization of metabolizable energy for milk production ( 5 multiparous cows).

\begin{tabular}{|c|c|c|c|c|c|c|}
\hline \multicolumn{7}{|c|}{ Dietary groups } \\
\hline & Barley & Oats & RSO & W1 & W2 & SEM \\
\hline \multicolumn{7}{|l|}{ Intake, } \\
\hline Dry matter, kg & 18.2 & 18.4 & 18.1 & 18.9 & 19.7 & 0.41 \\
\hline $\mathrm{DE}, \mathrm{MJ} \mathrm{d}^{-1}$ & 244.4 & 236.9 & 239.0 & 241.8 & 245.6 & 4.97 \\
\hline $\mathrm{ME}, \mathrm{MJ} \mathrm{d}^{-1}$ & 210.2 & 203.8 & 205.5 & 207.9 & 211.2 & 4.27 \\
\hline NE requirement & 122.5 & 126.5 & 127.9 & 121.2 & 127.5 & 3.90 \\
\hline For production $\left(\mathrm{NE}_{1}\right)$ & 86.7 & 85.3 & 88.1 & 82.1 & 80.8 & 1.88 \\
\hline For maintenance & 37.2 & 37.1 & 37.0 & 37.3 & 37.0 & 0.12 \\
\hline In weight change & -1.4 & 4.2 & 2.8 & 1.8 & 9.7 & 5.02 \\
\hline \multicolumn{7}{|l|}{ Efficiency } \\
\hline $\mathbf{k}_{1}^{\prime}$ & 0.57 & 0.58 & 0.59 & 0.55 & 0.52 & 0.024 \\
\hline $\mathrm{k}_{1}^{2}$ & 0.55 & 0.60 & 0.61 & 0.55 & 0.60 & 0.023 \\
\hline
\end{tabular}

$\mathrm{DE}$, digestible energy $=24.2 * \mathrm{DCP}+34.1^{*}$ digestible crude fat $+18.5^{*}$ digestible crude fibre $+17.0^{*}$ digestible nitrogen free extracts (HOFFMANN and SCHIEMANN 1980); ME, metabolizable energy $=0.86^{*} \mathrm{DE}$; NEl, net energy for milk production $=$ milk yield $*(0.383 *$ fat $\%+0.242 *$ protein $\%+0.165 *$ lactose $\%+0.0207)$ (BAEVRE et al. 1988); $k_{1}{ }^{1}$, ME for milk production corrected for maintenance and live weight change; $\mathrm{k}_{1}^{2}$, without considering live weight changes requirements; See Table 5. for SEM.

of ME in milk production between cows fed with oats and RSO, but cows fed with oats were more efficient than those fed with barley, when corrections were made for changes in live weight and for maintenance. Differences in body weight change were not significant $(\mathrm{P}>0.10)$ between treatments. However, the trend suggests that cows fed on barley were mobilizing more tissue than cows on other diets. 


\section{Milk fat fatty acids}

There was no significant $(\mathrm{P}>0.10)$ difference between diets on certain fatty acids such as $\mathrm{C}_{4 \cdot 0}$, $\mathrm{C}_{6: 0}, \mathrm{C}_{10: 1}, \mathrm{C}_{12: 1}, \mathrm{C}_{14: 1}, \mathrm{C}_{18: 3}$ and $\mathrm{C}_{20: 0}$ (Table 8). Concentrations of $\mathrm{C}_{12: 0}, \mathrm{C}_{14: 0}$ and $\mathrm{C}_{16: 0}$ decreased on oats and RSO feeding, but no apparent difference was observed between barley, W1 and W2 feeding on these fatty acids. Substitution of RSO for barley significantly decreased $(\mathrm{P}<0.001) \mathrm{C}_{16: 0}$ and increased $\mathrm{C}_{18: 0}$ and $\mathrm{C}_{18: 1}$ fatty acids compared to barley.

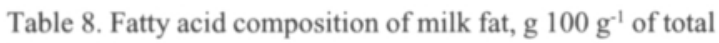
fatty acids.

\begin{tabular}{lrrrrrr}
\hline & \multicolumn{7}{c}{ Dietary groups } \\
& Barley & Oats & RSO & W1 & W2 & SEM \\
\hline C4:0 & 3.7 & 3.8 & 3.9 & 3.5 & 3.5 & 0.12 \\
C6:0 & 2.8 & 2.7 & 2.8 & 2.6 & 2.6 & 0.08 \\
C8:0 & 1.8 & 1.8 & 1.8 & 1.6 & 1.6 & 0.05 \\
C10:0 & 4.4 & 3.7 & 3.9 & 3.8 & 3.9 & 0.11 \\
C10:1 & 0.5 & 0.4 & 0.4 & 0.4 & 0.4 & 0.02 \\
C12:0 & 4.9 & 4.0 & 4.1 & 4.3 & 4.5 & 0.12 \\
C12:1 & 0.1 & 0.1 & 0.1 & 0.1 & 0.1 & 0.06 \\
C14:0 & 13.7 & 12.9 & 12.6 & 13.7 & 13.8 & 0.21 \\
C14:1 & 1.2 & 1.2 & 1.1 & 1.2 & 1.3 & 0.03 \\
C15:0 & 1.0 & 0.9 & 0.9 & 1.0 & 1.1 & 0.03 \\
C16:0 & 34.5 & 31.9 & 26.4 & 36.1 & 36.0 & 0.58 \\
C16:1 & 1.5 & 1.3 & 1.0 & 1.5 & 1.5 & 0.06 \\
C18:0 & 8.0 & 10.2 & 12.3 & 8.1 & 7.9 & 0.27 \\
C18:1 & 14.3 & 17.7 & 20.0 & 14.2 & 13.8 & 0.55 \\
C18:1 trans & 0.4 & 0.4 & 0.5 & 0.4 & 0.4 & 0.02 \\
C18:2 & 1.7 & 1.5 & 1.8 & 1.6 & 1.6 & 0.12 \\
C18:2Conj. & 0.3 & 0.4 & 0.4 & 0.4 & 0.4 & 0.02 \\
C18:3 & 0.4 & 0.4 & 0.4 & 0.5 & 0.5 & 0.01 \\
\hline & & & & & & \\
\hline
\end{tabular}

See Table 5, for SEM.

\section{Discussion and conclusion}

Two hypotheses were proposed in this experiment. The first hypothesis was that if part of the grain in the ration is replaced by fat/oil, the daily milk yield will not be higher than with the control concentrate feed, or it will be lower than with the control concentrate feed due to the negative effect of fatty acids on the rumen environment. The second hypothesis was that low energy lignocellulose feeds can sustain milk production when grass silage is provided ad libitum. The results confirmed however, that the daily milk yield can be increased by replacing part of barley with RSO but not with birch wood.

\section{Feed intake and digestion}

We observed increased silage DM intake and decreased concentrate intake by cows fed with oats compared to barley fed cows. This is contrary to the findings of MARTIN and THOMAS (1987) with lactating milking cows. The reduced silage intake by cows fed on RSO agrees with the work of STEELE (1985) where soya bean oil or crushed soya beans were added to silage and fed with supplementary protein. W1 and W2 fed cows consumed more silage to compensate the low energy content of the concentrate diet. Although there was a substantial difference in energy content of the test feeds, it seems that the difference in energy intake was compensated by higher silage intake by cows fed on W1 and $\mathrm{W} 2$.

The decrease in apparent digestibility of OM by cows fed with RSO was expected due to its toxic effect on cellulolytic organisms. However, the reduction in OM digestibility with RSO feeding observed in this trial was not significant. The absence of a negative effect on nutrient digestibility with RSO feeding to cows is in agreement with the reports of PALMQUIST and CONRAD (1978).

Under conventional feeding systems, the feeding of wood industry by-products to milking cows is not customary. A basic argument against its use is its low digestibility. Contrary to this, the apparent digestibility coefficient of OM was higher in cows fed W1 than in those fed with oats. In fact, it was observed that RSO and oats depressed the digestibility of NDF and ADF more than W1 did. The lower digestibility of OM, NDF and ADF observed with oats compared to barley and RSO feeding was not expected. We assume that this depression can 
be attributed to the exceptionally high fibre content of the oats used in this trial.

\section{Blood metabolites and milk yield}

It is expected that silage based diets that contain less fibre than hay based diets would interact with RSO or fat from oats to increase propionate production in the rumen (STEele and Moore 1968) and to increase blood glucose. This increased output of glucose then concomitantly increases plasma insulin which redirects fat synthesis from mammary tissue towards adipose tissues (VERNON 1980). However, in the present study neither glucose nor insulin concentration was significantly increased on RSO or oat feeding. Regarding plasma glucose concentration on RSO feeding, the result is contradictory to the previous observation with increasing level of rapeseed oil feeding to cows (TESFA et al. 1991). There were no significant changes in the BHBA or AA of blood plasma either. Therefore, the slight depression in the milk fat content seems not to have been caused by an alteration in concentration of blood metabolites on RSO diet. The observed slight increase in BHBA on RSO diet probably resulted from the oxidation of dietary fatty acids (STEELE 1984). The increase in BHBA, therefore, cannot be attributed to any pathological condition as the cows were in a positive energy balance during the observation. In the case of W1 fed cows, the elevated BHBA concentration could be due to high butyrate production in the rumen from the xylose contained in the birch wood.

An increased milk yield with oats compared to barley at a similar level of DM intake by the cows has been reported (HEIKKILÄ et al. 1988; LAMPILA and HeIKKILÄ 1986; MARTIN and ThOMAS 1987; MORAN 1986). In our study, despite similar DM intakes, cows fed with oats produced less milk than barley and RSO fed cows. Moss and PRIER (1981) also reported increased FCM yield on oat diet, although oats is inferior to other grain on the basis of its ME content. In the present study, oats depressed milk, FCM and protein yields compared to RSO.
RSO diet slightly increased milk and FCM yield and sustained milk protein yield but decreased milk fat and protein contents compared to barley. The reported depression in milk fat content with oats (MARTIN and Thomas 1987) and with canola oil (BEAUlieu et al. 1990) is in agreement with our observation with oat and RSO feeding.

The feed values of non-conventional feeds such as W1 and W2 are low compared to grain for high yielding milking cows. Owing to this fact, reduced milk yield was inevitable with W1 and W2 compared to both grain sources. The slightly higher or sustained milk fat content of cows fed with W1 and W2 can be viewed as a result of high intake of silage and higher fibre content of the birch woodbarley concentrate. This would have provided high output of acetate which in turn would be used to enhance de novo synthesis of short chain fatty acids of milk fat (MOORE and CHRISTIE 1979). However, the short chain fatty acid concentration of milk fat from cows fed with W1 and W2 was lower compared to that of barley fed cows.

The milk protein content has been found to respond to diets containing high fat negatively (DEPETERS et al. 1987, STEELE 1985). Compared to control diets, additional fat containing diets may cause a decrease in milk protein content but an increase in milk yield (BANKS et al. 1980), the protein yield remaining unchanged. Contrary to these findings, STEELE et al. (1971) observed an increase in milk protein yield on soya oil feeding.

When cows consumed complete diets containing $600 \mathrm{~g} \mathrm{~kg}^{-1} \mathrm{DM}$ as oats or barley, the oat diet reduced the milk protein content (MORAN 1986). MARTIN and THOмAs (1988) also observed decreased milk protein yield and content when cows were fed with oats. Although the effect of oats on the milk protein content varies slightly, our observation is in agreement both with the work of MARTIN and THOMAS (1988) and that of MORAN (1986). However, the higher negative effect of oats than RSO on the milk protein yield and content was not expected. The increase in milk urea content from cows fed with oat diet can be explained as a result of higher intake of crude protein. 


\section{Milk fatty acid composition}

The effects of oats on the fatty acid composition of milk fat resembled those observed in response to dietary fat containing diets (STORRY 1981; CLAPPERTON and BANKS 1985; TESFA et al. 1991). Depression in short- and medium chain fatty acids on oats and RSO was expected as the dietary unsaturated fatty acids are thought to reduce de novo synthesis of $\mathrm{C}_{6: 0}-\mathrm{C}_{16: 0}$ fatty acids within the mammary gland through a reduced supply of acetate, which apparently inhibits mammary acetyl-CoA decarboxylase (ClaPPERTON and BANKS 1985; MATTOS and PALMQUIST 1974). The increase in the proportions of $\mathrm{C}_{18: 0}$ and $\mathrm{C}_{18: 1}$ in milk fat on RSO and oat diets is due to the hydrogenation of unsaturated fat in the rumen and subsequent intramammary desaturation of the $\mathrm{C}_{18: 0}$ formed (BANKS et al. 1980; CHRISTIE 1981). RSO raised the proportion of C18:1 transfatty acid in milk fat, similar to the reports of KEN-
NELLY (1987) with diets containing full-fat canola seed. The elevated trans- fatty acid is a result of the hydrogenation of oil in the rumen as has been observed in our previous study (TESFA et al. 1991).

Based on the results obtained in this study, both oats and RSO diets showed a substantial reduction in $\mathrm{C}_{10: 0}-\mathrm{C}_{16: 0}$ fatty acid content of milk fat with a concomitant increase in $\mathrm{C}_{18: 0}$ and $\mathrm{C}_{18: 1}$. However, oat feeding and replacing barley with RSO was observed to result in decreased milk protein content. Although there is a need, both nutritionally as well as technologically, for changing the fatty acid composition of milk fat, the emphasis should not be put on replacing grain with fat. Because replacing grain with fat reduces the availability of fermentable carbohydrate which could be used as energy sources by rumen microbes. Therefore, oil should be used as a supplement to the basal diet rather than as a replacement.

\section{References}

Baevre, L., Junkkarinen, L., Pedersen, J., Setälä, J. \& SJAUNJA, L.O. 1988. A Nordic proposal for an energy corrected milk (ECM) formula. International committee for recording the productivity of milk animals (ICRPMA) 26th session.

Banks, W., Clapperton, J.L. \& Kelly, M.E. 1980. Effect of oil-enriched diets on the milk yield and composition, and the composition and physical properties of the milk fat, of dairy cows receiving a basal ration of grass silage. J. Dairy Res. 47: 277-285.

Beaulieu, A.D., Olubobokun, J.A. \& Christensen, D.A. 1990. The utilization of canola and its constituents by lactating dairy cows. Anim. Feed Sci. and Technol. 30: 289-300.

Bender, F., Heaney, D.P. \& Bowden, A. 1970. Potential of steamed wood as a feed for ruminants. For. Prod. J. 20: 36-41.

Butterbaugh, J.W. \& JohnSON, R.R. 1974. Nutritive value of acid hydrolysed wood residue in ruminant rations. J. Anim. Sci. 38: 394-403.

Christie, W.W. 1981. The effect of diet and other factors on the lipid composition of ruminant tissue and milk. In: Christie, W.W. (ed.). Lipid Metabolism in Ruminant Animals. Pergamon Press Oxford. p. 193-226.

Clapperton, J.L. \& Banks, W. 1985. Factors affecting the yields of milk and its constituents, particularly fatty acids, when dairy cows consume diets containing added fat. J. Sci. Food Agric. 36: 1205-1211.

Depeters, E.J., Taylor, S.J., Finley, C.M. \& Famula, T.R. 1987. Dietary fat and nitrogen composition of milk from lactating cows. J. Dairy Sci. 70: 1192-1201.

FISHER, L.J. 1980. An evaluation of steam-treated aspen as a substitute for corn silage in the rations of lactating cows. Can. J. Anim. Sci. 60: 379-384.

GoERING, H.K. \& VAN Soest, P.J. 1970. Forage fibre analysis. U.S.D.A. Agricultural Handbook, No. 79.

HANSEN, J.L. \& FrEIER, E.F. 1978. Direct assays of lactate, pyruvate, B-hydroxybturate, and acetoacetate with centrifugal analyzer. Clin. Chem. 24: 475-479.

HeIKKILÃ, T., VÃÄTÃINEN, H. \& LAMPILA, M. 1988. Barley or oats for dairy cows. Procedigs VI World Conference on Animal Production. 2.119 (Abst.)

Hoffmann, L. \& SchiemanN, R. 1980. Von der Kalorie zum Joule: Neue Größenbeziehungen bei Messungen des Enegieumsatzes und bei der Berechnung von Kennzahlen der energetischen Futterbewertung. Arch. Für Tierenährung. 30: 733-742.

KENNELLY, J.J. 1987. Full-fat canola seed for lactating dairy cows. In: Research on canola seed, oil, meal and meal fractions, 8th progress report. 63: 257-262. Canola 
Council of Canada, Winnipeg.

LAMPILA, M. \& HeIKKILÄ, T. 1986. Ohraa vai kauraa lypsylehmille? Karjatalous 62: 35-36.

MAFF. 1975. Energy allowance and feeding systems for ruminants. Tech. Bull.33. 79 p. London.

Martin, P.A \& Thomas, P.C. 1987. Milk yield and composition in cows given barley or oats as supplements to grass and lucerne silage. Eight silage conference. AFRC, IGAP, Herley. p. 177-178.

— \& Thomas, P.C. 1988. Dietary manipulation of the yield and composition of milk: Effects of dietary inclusion of barley and oats in untreated or formaldehyde treated forms on milk fatty acid composition. J. Sci. Food Agric. 43: 145-154.

MATTOS, W. \& PALMQUIST, D.L. 1974. Increased polyunsaturated fatty acid yields in milk of cows fed protected fat. J. Dairy Sci. 57: 1050-1054.

Millett, M.A., BaKer, A.J., Feist, W.C., Mellenberger, R.W. \& SATTER, L.D. 1970. Modifying wood to increase its in vitro digestibility. J. Anim. Sci. 31: 781-788.

MiYамото, S. et al. 1986. Feeding trial of lactating cow by steamed white birch (the first report). Jpn. Soc. Zootech. Sci. 78 Ann. Meeting Abs. 60.

MOORE, J.H. \& ChristIE, W.W. 1979. Lipid metabolism in the mammary gland of ruminant animals. In: Holman, R.T. (ed.). Progress in Lipid Research. Vol. 17. 366 p. Pergamon Press, Oxford.

Moran, J.B. 1986. Cereal grains in complete diets for dairy cows: A comparison of rolled barley, wheat and oats and of three methods of processing oats. J. Anim. Prod. 43: 27-36.

Morrison, W.R. 1977. Cereal lipids. Proc. Nutr. Soc. 36: 143-148.

Moss, B.R. \& Prier, S.G. 1981. High levels of barley in rations for calves and lactating cows. J. Dairy Sci. 64: suppl. 1: 128 (Abstr.).

PALMQUist, D.L \& ConRAD, H.R. 1978. High fat rations for dairy cows. Effects on feed intake, milk and fat production, and plasma metabolites. J. Dairy Sci. 61: 890-901.

RAJAMĂKI, S. \& RAURAMAA, A. 1984. The automated determination of urea in milk. Finn. Chem. Lett. 2: 47-48.

Reddy, M.R., Deyoe, C.W. \& Harbers, L.H. 1972. Processing of cellulosic materials. 2. Processed sawdust in high energy rations. Ind. J. Anim. Sci. 42: 886-890.

SAlo, M., TUORI, M. \& KIISKINEN, T. 1982. Rehutaulukot ja ruokintanormit. 70 p. Helsinki.

STEELE, W. 1984. Lipid supplementation of dairy cow diets. J.Dairy Sci. 67: 1716-1724.

- 1985. High oil, high protein diets and milk secretion by cows. J. Dairy Sci. 68: 1409-1415.
— \& MoORE, J.H. 1968. The effects of a series of saturated fatty acids in the diet on milk-fat secretion in the cow. J. Dairy Res. 35: 361-370.

-, NoBle, R.C. \& MoORE, J.H. 1971. The effects of 2 methods of incorporating soyabean oil into the diet on milk yield and composition in the cow. J. Dairy Res. 38: 4348.

Steele, R.G.D \& Torrie, J.H. 1960. Principles and procedures of statistics. McGraw-hill Book Company, Inc. USA.

StorRy, J.E. 1981. The effect of dietary fat on milk composition. In: Harresign, W. (ed.). Recent Advances in Animal Nutrition. p. 3-33.

TAKIGAWA, A. 1987. Feeding value of steamed wood and explosively depressurized wood. JARQ. 20: 281-291.

TARKOW, H. \& FEIST, W.C. 1969. A mechanism for improving the digestibility of lignocellulosic materials with dilute alkali and liquid ammonia. In: Cellulase and their applications. Adv. Chem. Ser. 95: 197-217.

TERADA, F. ET AL. 1986. Digestibility and nutritive value of the steamed and steam-exploded birch by goats. Bull. Nat. Ins. Animal Ind. 44: 55-59.

Tesfa, A.T., TuOri, M. \& SyrjäLÄ-Qvist, L. 1991. High rapeseed oil feeding to lactating cows and its effect on milk yield and composition. Finn. J. Dairy Sci. 49: 6581 .

TUORı, M. 1990. Lignoselluloosapitoiset rehut märehtijäin ruokinnassa. Suom. Maatal.tiet. Seur. Tied. no 13: 47 56.

TYÖPPÖNEN, J. \& KAUPPINEN, K. 1980. The stability and automatic determination of keone bodies in blood samples taken in field conditions. Acta Vet. Scand. 21: 5561.

VERNON, R.G. 1980. Lipid metabolism in the adipose tissue of ruminant animals. In: Holman, R.T. (ed.). Progress in lipid research. p. 92. Pergamon Press, Oxford.

Williams, C.H., David, D.J. \& IIsmaA, O. 1962. The determination of chromic oxide in faeces samples by atomic absorption spectrophotometry. J. Agric. Sci. 59: 381385.

Manuscript received January 1992

Alem Tsehai Tesfa

Mikko Tuori

Liisa Syrjälä-Qvist

Kaisa Kaustell

University of Helsinki

Department of Animal Science

SF-00710 Helsinki, Finland 


\title{
SELOSTUS
}

\section{Ohra, kaura sekä osittain rypsiöljyllä tai höyryräjäytetyllä koivulla korvattu ohra säilörehuvaltaisella ruokinnalla lypsylehmillä}

\author{
Alem Tsehai Tesfa, Mikko Tuori, LiISA SyruäLÄ-Qvist ja Kaisa Kaustell
}

Helsingin yliopisto

Tässä kokeessa tutkittiin energiatäydennyksen vaikutusta maitotuotokseen ja maidon koostumukseen korkean maidontuotantokauden aikana säilörehuvaltaisella ruokinnalla. Văkirehun energiavăkevyyttă lisăttiin rypsiöljytăydennyksellå tai energiavăkevyyttä văhennettiin vaihtamalla văkirehun ohra kauraan tai korvaamalla osa ohrasta höyryräjäytetyllä koivulla. Viimeksimainittu tuote oli valmistettu ns. Stake-prosessilla, missä haketettu koivu kuummennetaan kyllåstetyssä vesihöyryssä yli $200^{\circ} \mathrm{C}$ :seen. Kun paine äkillisesti alennetaan, lehtipuun hemiselluloosa hydrolysoituu ja tulee vesiliukoiseksi. Entsyymit pystyvät tälloin hajottamaan helpommin selluloosaa, ja myős ligniinistä osa hajoaa ja tulee liukoiseksi. Koivun hydrolysoituneet ksylaanit voidaan uuttaa vedellä ja käyttää esim. ksylitolin raaka-aineena. Tässä kokeessa ollut höyryräjäytetty koivu oli joko uuttamatonta tai vesipestyä (ksylaanit poistettu).

Kokeessa oli kymmenenen Ay-lehmää (5 ensikkoa ja 5 usean kerran poikinutta). Koekaaviona oli kaksi 55 tasapainoitettua latinalaista neliötä. Kontrolliruokinnalla văkirehun vilja oli ohraa. Kauraruokinnalla vilja oli kauraa. Rypsiöljyruokinnalla (RSO) vilja oli ohraa kuten kontrolliryhmälläkin, mutta $0.4 \mathrm{~kg}$ ohrasta oli korvattu 0.4 kilolla rypsiöljyllä. Kahdella viimeisellä ruokinnalla $2 \mathrm{~kg}$ văkirehun ohrasta oli korvattu joko höyryräjäytetyllä koivulla (W1) tai vesipestyllä höyryräjäytetyllä koivulla (W2). Väkirehussa annettiin lisäksi $1.3 \mathrm{~kg}$ soijarouhetta päivässä. Väkirehun kokonaismäărä oli kaikilla ruokinnoilla sama, $8 \mathrm{~kg}$ päivăssä, koko kokeen ajan. Säilörehua annettiin ad libitum. Kokeessa oli viisi neljän viikon pituista jaksoa. Tulokset on laskettu jaksojen kahden viimeisen viikon tiedoista.

RSO-ruokinnalla säilörehun syönti ja kokonaiskuivaaineen saanti oli hieman pienempi kuin kontrolliruokinnalla (10.1 ja 17.1 vs. 10.6 ja $\left.17.4 \mathrm{~kg} \mathrm{ka} \mathrm{d}^{-1}\right)$. Muuntokelpoisen energian saanti RSO-ruokinnalla oli kuitenkin suurempi kuin kontrolliruokinnalla (201 ja 195 MJ/d). Kauraruokin- nalla väkirehun kulutus (6.2 $\left.\mathrm{kg} \mathrm{ka}^{-1}\right)$ oli alempi, koska väkirehua jätettiin tällä ruokinnalla enemmän syömättä kuin muilla ruokinnoilla. Säilörehun syönti oli $11.2 \mathrm{~kg} \mathrm{ka} \mathrm{d}^{-1} \mathrm{ja}$ kuiva-aineen kokonaiskulutus 17.4 kg ka d ${ }^{-1}$ kauraruokinnalla. Höyryräjäytettyä koivua saaneilla ruokinnoilla säilörehun kulutus oli 10.8 (W1) ja $11.7 \mathrm{~kg} \mathrm{ka} \mathrm{d}^{-1}$ (W2) sekä kuiva-aineen kokonaiskulutus vastaavasti 17.8 ja 18.4 kg ka $\mathrm{d}^{-1}$.

Dieetin orgaanisen aineen sulavuus oli merkitsevästi alempi W2- $(\mathrm{P}<0.01)$ ja kaura-ruokinnoilla $(\mathrm{P}<0.05)$ kuin ohraruokinnalla $(69.6,70.9$ ja $75.2 \%)$. NDF:n sulavuus oli alin kauraruokinnalla ja korkein ohraruokinnalla (60.7 ja $67.7 \%, \mathrm{P}<0.05$ ). ADF:n sulavuus W2-ruokinnalla oli alin, ja ero ohraruokintaan oli merkitsevä (60.7 ja $67.1 \%$, $\mathrm{P}<0.05$ ). Myös kaura- ja RSO-ruokinnalla oli suuntausta alentuneeseen ADF:n sulavuuteen (62.2 ja 62.9\%).

RSO-ruokinnalla oli korkein maitotuotos, $25.5 \mathrm{~kg} \mathrm{~d}^{-1}$, ja ero kaura-, W1- ja W2-ruokintoihin oli merkitsevă (24.2, 23.3, $22.9 \mathrm{~kg} \mathrm{~d}^{-1}, \mathrm{P}<0.05$ ). Ohraruokinnalla maitotuotos oli $24.6 \mathrm{~kg} \mathrm{~d}^{-1}$ (n.s.). Vaikka maidon rasva- ja valkuaispitoisuuksissa ei ollut tilastollisesti merkitseviä eroja ruokintojen välillä, oli tendenssinä sekä kaura- että RSO-ruokinnalla maidon alentunut valkuaispitoisuus. Maidon ureapitoisuus oli kauraruokinnalla korkein $(37.6 \mathrm{mg} / 100 \mathrm{ml})$. Ero muihin ryhmiin oli merkitsevä $(\mathrm{P}<0.01)$. Sekä kaura että rypsiöljy lisäsivät $\mathrm{mm}$. maitorasvan steariinihapon ja öljyhapon osuutta verrattuna muihin ruokintoihin.

Tässä kokeessa $5 \%$ rypsiöljyä väkirehussa vaikutti positiivisesti maitotuotokseen. Kaura- ja ohraruokinnoilla maitotuotoksessa ei ollut suurta eroa. Sekä RSO että kaura alensivat maidon valkuaispitoisuutta. Lignoselluloosatuotteiden (höyryräjäytetyt koivut) sisällyttäminen dieettiin (15\% väkirehuseoksessa) alensi maitotuotosta, eikä niiden rehukäyttö tässä mitassa ole kannattavaa. 